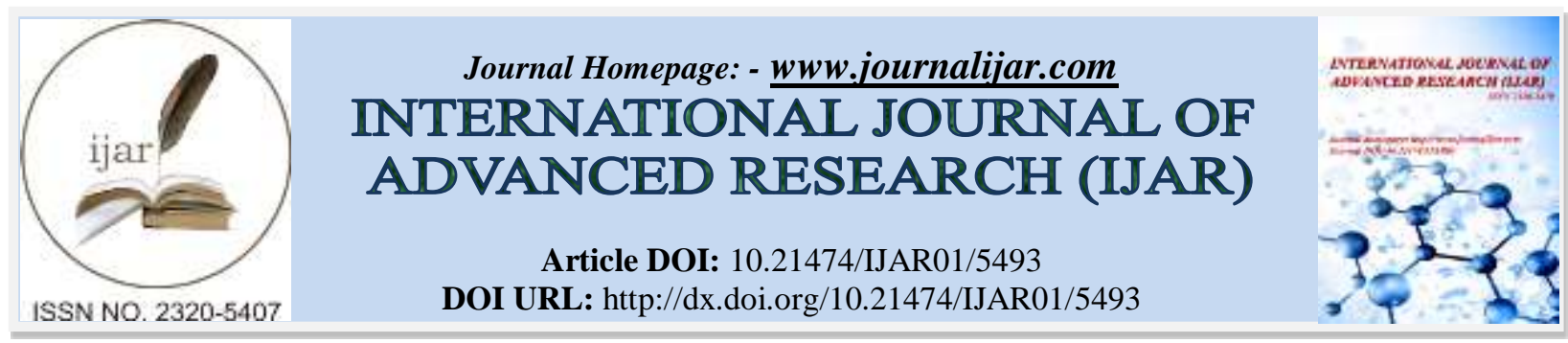

RESEARCH ARTICLE

\title{
GLIMPSES OF RAVENSHAW COLLEGE STUDENTS' MOVEMENTS BEFORE THE INDEPENDENCE OF INDIA, AS DESCRIBED BY SOME VETERAN RAVENSHAWVIANS AND STUDENT LEADERS.
}

Biplab Siladitya and M. A. M. Phil.

\section{Manuscript Info}

............................

Manuscript History

Received: 21 July 2017

Final Accepted: 23 August 2017

Published: September 2017
Abstract

Copy Right, IJAR, 2017,. All rights reserved.

"To me, Ravenshaw is the greatest monument to be built in Orissa after the Konark temple in the $13^{\text {th }}$ Century. The difference is that Konark was abandoned and ruined, while Ravenshaw is vibrant with the hope and aspiration of its 7000 students." 1

It is a fact that almost all builders of modern Orissa, beginning from Dr. Harekrushna Mahtab (Subsequent Prime Minister and Chief Minister of Orissa, Governor of Bombay and Union Cabinet Minister of India), Nabakrushna Choudhury (Subsequent Prime Minister of Orissa), Biju Patnaik(Subequent Chief Minister of Orissa and Union Cabinet Minister of India), Biren Mitra (Susequent Chief Minister of Orissa), Nilamani Rautray (Subsequent Chief Minister of Orissa and Union Cabinet Minister of India), Nandini Satapathy(Subsequent Union Minister and Chief Minister of Orissa), Janaki Ballav Patnaik(Subsequent Chief Minister of Orissa, Governor of Assam and Union Cabinet Minister of India), Rabi Ray(Subsequent Cabinet Minister and Speaker of India), Bibhudhendra Mishra(Susequent Union Minister in the Ministry of Nehru, Shastree and Indira Gandhi), were students of Ravenshaw College before the independence. In a system, the leader is more important than his fellow people. A good leader can change the fate of a society, but so many learned men cannot do anything without a good leader. Rightly, it was said by Alexander the Great that, "I am not afraid of an army of lions led by a sheep; I am afraid of an army of sheep led by a lion."

Not only in politics, Ravenshaw has produced many eminent educationist, scientists and eminent people in different field of India. But "Kautilya holds that there are, indeed, four branches of knowledge. Because one can know from these four all that is to be learnt about dharma [spiritual welfare] and artha[material well-being], they are called 'knowledge'."' According to Arthashastra, [traditionally,] the three Vedas, philosophy, the science of government and economics are four branches of knowledge. But the followers of Manu say believe that only there are three branches-economics, the three Vedas and science of government. The school of 'Brihaspati' considers economics and politics as only true branches of knowledge. But 'Ushanas' school maintains that all other sciences have their beginning and end in the science of politics, for which it is the only source of knowledge. ${ }^{3}$

Our freedom is not a perpetual gift of nature, since nature is naturally ruled by "Fish Rule" or "Jungle Rule", with might is right principle. Therefore, freedom is attained and retained with efforts in politics. In his famous book, ' $A$ Grammer of Politics', the eminent Proffessor and Politician, Harod J. Laski, has quoted a lime of HENRY W. NEVINSON, from his Essays in Freedom,( p.xvi), which says that "For freedom, we know, is a thing that we have 
to conquer afresh for ourselves, every day, like love; and we are always losing freedom, just as we are always losing love, because, after each victory, we think we can now settle down and enjoy it without further struggle.... The battle of freedom is never done, and the field never quiet."

Therefore, in this article there is an effort to point out some event of freedom struggle wherein students were leader and victims. The statements of some eminent people of Orissa have been referred to through some light on the student politics of Ravenshaw College during their time, which has become a glorious chapter in modern history of Orissa.

Since 1920, the 'Satyabadi Mess' of Ravenshaw College was known as 'Utkal Swaraj Ashram' when Gopabandhu Das started staying there. It became a breeding ground of Satyagrahis, especially after visit by Gandhiji on 23 March 1921. It had influenced Ravenshaw college students for participation in our national movements.

The politics of students during that time may be seen from an article of Nilmala Kumari Mohapatra on Pdmashree Dr. Mayadhar Manasingha, which reads as follows:

"On sad demise of Gopabandhu Das, $\left(17^{\text {th }}\right.$ June 1928$)$ poet Manasingha wrote three poems in Odia language and an Essay in English language which was published in Ravenshaw College magazine. In pre-independence period, expecially during the time span 1909-28, Gopabandhu Das was considered as an opponent and anti-personage to the then Govt. as he was an active social reformer, journalisht, member of legislative council. Moreover he was the chief leader to assail the Non-Co-operation Movement as per the wish of Mahatma Gandhi. Young poet Mayadhar's writing conveys his deep reverence for Utkalmani Gopabandhu. This sort of great admiration for a freedom fighter was taken as a minus point in Mayadhar's career. The Principal, Ravenshaw College Mr. Ogil Sahib sent a confidential report for the post of a Deputy Magistrate that he wants to be in both the campus. So Mayadhar could not become the Deputy Collector whereas people of fewer calibers could hold that alluring job." 5

Besides the Non-Cooperation Movement, Odisha students had many other tastes of agitation politics since the early twenties. For instance, a protest agitation was started by the students of the East Hostel of Ravenshaw College against non-inclusion of their names in the voters' list for the municipal election in 1922. First of all, Harihar Mohapatra raised this issue, but nobody listened to him. Then, he met the Chairman Srijukta Rama Sankar Ray with a handwritten representation, signed by boarders of the hostel. The ground was, to be a voter, some body most be a resident only, not a permanent resident. This was finally allowed and hostel borders became voters, but lecturers could not be included, as the last date for inclusion was over. ${ }^{6}$

Similarly, in 1924, when students were organizing a meeting under the banner of "All Orissa Students' Conference" at Cuttack, an attempt was made by the Collector to dissuade the students from attending it. The third year student Harihar Mohapatra, who was closely associated with Students' Federation from Puri Conference, was its main organizer. For this conference, Pranakrushna Parija was agreed to be the Chairman of Reception Committee. Reception Committee Office was functioning from the Ravenshaw College Hostel with permission of the Warden. As Godabarsh Mishra was invited as the President of the Conference, Government decided to withdraw the permission and became determined not to allow for such conference inside Ravenshaw College. ${ }^{7}$

Sri Nilamani Rautroy had stated that in 1938, in our educational institutions of Odisha, dark-rule and whimsical principles were prevailing. The Principal and lecturers of Ravenshaw College were having no sympathy for the problem of students. Students have no independence in any matter. Students were afraid of Principal and lecturers. By organized students' movements, the views of students as well as lecturers were changed. After many movements and tussles, Ravenshaw College students' union was recognized as a democratic organization. ${ }^{8}$

The role of students' movements in the massive national freedom struggle is like the small roots of a huge shade providing Banion tree, for collecting food for the said tree. The movements of students, workers and peasants in our country for their small democratic rights, though seem to be small, these were essential for organizing a massive national level movement. It seems from outside, a struggle between students and principal, workers and owners, peasants and zamindars, but that is a meanminded unrealistic evaluation. These movements were complementary to each other and meant for a dreamed India and to build our future, by raising and preserving energy. Principal Parija Saheb had a wrong impression that the agitating students are desirous of becoming College Union President. Finally, proposal was given for a voting not to elect President, but to know the view of students. A day was fixed for 
election, after seven days. A group of students under the leadership of Biren Mitra, came forward openly to support the Principal's view of no election for students' union. Therefore, one day, the quarter of principal was gheraoed by students. The day of election came. By four votes, we won. Students' Union got freedom to be controlled by students' votes. After this, for the first time student leader Sri Manmohan Mishra(Former Chairman of Cuttack Municipality) was elected as the First President of Ravenshaw College Students' Union, elected by students. ${ }^{9}$ Baidyanath Mishra(Former VC) has also noted that, in the year of 1938, the first Students' Union was constituted. ${ }^{10}$

Dr. Shreeram Chandra Dash (renouned Proffessor), has wrote that "On the issue of Law Professor Jitendra Nath Banarjee, there was a student movement in 1938. There was a strike in hostel to withdraw drill class from hostel. The strike spread to East Hostel and College level. Then D.S.A. President was Birendra Mohan Patnaik (subsequent Advocate General) and Secretary was Bidhubhusan Das (subsequent Higher Education Director). They were also involved in this strike. At that time, Harekrushna Mahtab and some other congress leaders were trying to fuel this strike by motivating some students. ${ }^{5}$ On $26^{\text {th }}$ January 1940 , Nilamani Rautroy and Bibhudhendra Mishra unfurled the national flag over our college building, without obeying the order of the principal. They were fined fifty rupees each, rusticated from the college and Patna University was informed not to allow them to appear graduation. The students of the college started a strike on this issue. When we were going in one rickshaw, police stopped us and arrested Surajmal Shah. When asked my name, out of fear, I told my name as Ramachandra Mishra, name of a student and communist leader. I was also arrestd and made to sit in vehicle. That day the police incharge of Cuttack was Sripati Mishra, who knew me. When Sripati Mishra told that he knew me, my name is Shreeramachandra Dash, they released me. Arta Babu took me inside, by saying that the strike has been called up. At that time, some one told that "Manmohan Mishra died in police assault. His dead body is laying on tennis court." Manmohan Babu then sixth year student. He was a meritorious student. In fact Manmohan was alive. He was senseless due to huge bleeding from his head. $" 6$

Similarly, Bibhudhendra Mishra, has recalled in his autobiography, that "January 26, 1940 was the Independence Day. Then in entire country, only student organization was 'Student Federation', which was very strong in Orissa. After the victory in 1939 Medical School Strike against Congress Government, we had a strong unity and strength. For unfurling national flag legally inside the college, I alongwith Nilamani Rautroy, sought permission of Principal Parija Saheb, but he refused. But, national flag was hoisted inside college. On $16^{\text {th }}$, we were served with an order of the Patna University Syndicate to the effect that, if we do not tender unconditional apology with payment of fine of Rs.25/-, we can not appear in the next B.A.Examination. ${ }^{7}$

We, both, have decided not to beg apology and went to cinema. After returning from cinema, we saw at tennis court, Ramakrushna Pati, Viswanath Pasayat, Baidyanath Mishra, Anata patnaik, Sachi Rautray, Ashok Das, Gangadhar Mohapatra, Manmohan Mishra, Surajmal Shah, Bijay Chandra Das, Banamali Patnaik, Durgacharan Mohanty and Ramachandra Mishra and many other comrades arrived there. It was decided to start strike on the next day. Complete Hartal. One day...two day...three day. Classes found empty. All students were gathered at tennis court, meetings continued, there is deep sence of satisfaction in the face of all students. Due to strike, authority was panicstriken. The move for settlement failed. Electricity and water connections were disconnected from the hostels. Throughout night fire was set on the road at various places and there were mashal (hand made torch of fire) procession and meetings. Entire town was tensed. ${ }^{8}$

In one night, in a meeting it was declared that Ravenshaw College has become a 'Republic'. Parija Saheb went to his Cantonment house. All of a sudden, one day Ashok Das and Sachi Rautroy were arrested on the allegation of 'criminal tresspass'. It led to boycotting examinations and burning admit cards. On $25^{\text {th }}$ February, college beame like an Army Camp, forces from Peswar were brought to suppress the movement. At that time, Pradesh Congress Committee Office was functioning at Janakinath Bhawan of Odia Bazar. Our strike continued. ${ }^{9}$

After a procession, I was arrested alongwith Baidyanath Rath. The procession of students saw us near Mangalabag and gheraoed our vehicle. After some time, vehicle moved to Lalbag Police Station. Many students were injured in lathicharge by police on $26^{\text {th }}$. Examination was started with the help of teachers and police. Three days after, Manmohan Mishra and Banamali Patnaik and others were arrested and remained with us in jail." 10

In the 1940 Students' Strike, student leaders were released on bail after some time, but convicted with fine of Rs.50/- each, and in its non-payment one month imprisonment. However, in the appeal, Judge Maher Saheb acquitted everybody. ${ }^{11}$ 
Janaki Ballav Patnaik was reading in B.A. at Ravenshaw College, who had formed Chhatra Congress with Pradipta Kishore Dash (former Minister), Rabi Ray and others. Pradipta Kumar Das was the President of the Chhatra Congress. ${ }^{12}$ In January 1947, Manmohan Mishra, started 'Union Jack Removal' movement. Janaki Ballav had declared West Hostel as a 'Soverign Republic', for which he was removed from college. Against such arbitrary step, there was a strike in Ravenshaw and all other education institution of Cuttack. At that time, the Prime Minister was Harekrushna Mahtab. College authorities announced that in all function infuture, Union Jack will be replaced by Tricolor National flag. ${ }^{13}$ In his 'Asamapta Atmalipi', Janaki Ballav has stated that when there was a move for unofficial agreement, to take credit, Manmohan Mishra shouted and call was given for strike. ${ }^{14}$ After release of the students' leaders, those were arrested in August Revolution, Students' Federation was devided in two groups, one as the student organization of communist supporters and Chhatra Congress became anti-communist students' organization. $^{15}$

In the autobiography of Rabi Ray, which was written as per the description of Rabi Ray, it is noted that Rabi Ray while studying in Ravenshaw College, had joined Chhatra Congress in 1944 and became the President of its Cuttack District Committee, when Pradipta Kishore Ray was its State President. In that year, Pradipta Kishore Das and Rabi Ray (3rd year), were elected as Union President and Day Scholar Association Secretary, respectively. In 1946, Student Union President Pradiptra Kumar Das with Manmohan Mishra of Students' Federation and other students, Union Jack was removed and turned in pieces. Harekrushna Mahtab was Prime Minister of Orissa and opposing the actions of students. At his instance, many students were removed from college. Mahtab took this issue as a challenge. In its protest, there was a state-wide student movement. A massive rally was started from Ravenshaw College and preceded to Gourisankar Park and a public meeting was held there. Many student leaders, including firls like Nirupama, were arrested at that place. It was first imprisonment of Rabi Ray. This of Orissa was discussed in national level and such steps of Ravenshaw College students were considered as a heroic step. Finally, government accepted all demands of students and taken back the students, those were rusticated and removed from college and Govt. decided to replace Union Jack with tricolor flags in all educational institutions. It was first in entire country. At that time another important development took place. West Hostel students decided to declare their hostel as a"Republic". Therefore, they have choosen a good student not associated with politics and elected Janaki Ballav Patnaik as their Hostel President. Hostel Superintendent Srinibas Sahoo was imprisoned inside the hostel and Principal S. Ray was not allowed to enter inside the hostel. Prime Minister wanted to send police to enter inside the hostel, but Principal did not accord permission in this regard. Finally, there was an amicable settlement. At that time, Mohapatra nilmani Sahoo, Debiprasanna Patnaik, kulamani Mohapatra, etc. were boarders of West Hostel. ${ }^{16}$

Rabi Ray was not believing in caste system, for which in the column prescribed for mentioning caste during examination, he had put a cross mark and therefore, he was not allowed to appear examination, though subsequently, he was called by the Principal to appear the examination. ${ }^{17}$

Biju Patnaik was an eminent student leader of Ravenshaw College, who was more interested in daring and sporting activities, though associated with politics. He had travelled in a cycle from Cuttack to Peswar in 1932, when he was reading I.Sc. in Ravenshaw College. ${ }^{18}$ He was adjudged as the Ravenshaw BLUE though he was a not a simple blue, but a "Indra Nilamani"(which is seen in Crown of Vishnu) of Ravenshaw College and Odisha province and acquired many International Award for his heroic work.

\section{Notes \& References:-}

1. Lalit Mansingh, First Foundation Day Lecture of Ravenshaw University, Published in 'THE RAVENSHAWVIAN', By Ravenshaw University, Cuttack, 2009, pp.45, 46.

2. Kautilya, 'The Arthashastra', Edited, Rearranged, Translated and Introduced by L.N.Rangarajan, Published by Penguin Books India Ltd., New Delhi, 1987, p.83;Ibid.

3. Lasky, Harold J., 'A Grammer of Politics', Published by: George Allen \& Unwin Ltd., London in 1925, p. Inner cover.

4. Nirmala Kumari Mohapatra, Padmashree Dr. Mayadhar Manasingha-A Brief Study, (Odisha Review, Nov2014), p.41.

5. Justice Harihar Mohapatra, Jiban O Jibika,(Odia), Lark Books, Cuttack, 1987, pp. 149, 150.Ibid, pp.155, 156.

6. Nilamani Rautroy, Smruti O; Anubhuti, Grantha Mandir, 2001, pp.90-92. Ibid, pp.93, 94.

7. 10Baidyanath Mishra, JI,BAN GANGOTRI-GAON MATI, Vidyapuri, Cuttack, 2001, P.75.

8. 5. Shreeram Chandra Dash, MO AKUHA KAHANI, Cuttack Students' Store, Cuttack, 2003, p.48.

9. 6. Ibid, p.53. 
10. Bibhudhendra Mishra, JIBAN JATRA PATHARE, Grantha Mandir, Cuttack, 2006, p.42.

11. Ibid, pp.42-44.

12. Ibid, pp.45-46..

13. Ibid, pp.48-50.

14. Ibid, pp.50-52.

15. Govinda Bhuyan, Sarthak Sarathi (life history of Janaki Ballav Patnaik), Vidyapuri, Cuttack, 1998, p.9.

16. Ibid, pp.9-10.

17. Janaki Ballav Patnaik, Asamapta Atmalipi, Published by Ama Odisha, Bhubaneswar, 2016, p.58.

18. Ibid, p.38.

19. Sulochana Das, Matiru Akash()Life History of Rabi Ray), Vidyapuri, Cuttack, 2005, pp.40-48.

20. Ibid, p.48.

21. A visionary Leader of the Country(Articles on Biju Patnaik), Edited by Nilambar Rath, Publisher-Academy for Media Learning Private Limited, Bhubaneswar, 2016.

*The author is a Research Scholar, Department of History, Ravenshaw University, Cuttack, Orissa, India, PIN753003, (Mobile-9861092222.) 2984 words. 